\title{
Adapting usability heuristics to evaluate Facebook according to elderly
}

\author{
Ivana Harari ${ }^{1}$ \\ Javier Francisco Diaz ${ }^{2}$
}

Sandra Baldasarri ${ }^{3}$ 


\section{Resumen}

La inspección de usabilidad es un método de evaluación llevada a cabo por uno o más expertos en $\mathrm{HCl}$, sujetos con bases teóricas y prácticas sólidas para la obsenvación formal y objetiva de un producto. Uno de los métodos más utilizados es la evaluación heurística, término acuñado por Jakob Nielsen en 1989, que consiste en utilizar un set de heurísticas de usabilidad para examinar el producto y analizar su grado de cumplimiento. Debido al uso de Facebook cada vez mas extensivo por parte de adultos mayores, se realiza en este artículo una evaluación heurística sobre esta aplicación, donde principios de usabilidad han sido adaptados para adecuarlos al perfil de un adulto mayor como a su interacción con las cuestiones colaborativas y funciones de groupware que caracterizan a las redes sociales. Resultados de este proceso de inspección será de suma importancia para entender si las aplicaciones actuales consideran al adulto mayor como posible usuario de las mismas, respetando principios de usabilidad acordes a dicho perfil.

Palabras-clave: Interacción Persona Ordenador; Usabilidad; Experiencia del usuario; Diseño centrado en el usuario; Groupware.

\section{Abstract}

A usability inspection is an evaluation method carried out by one or more experts in $\mathrm{HCl}$, individuals with solid theoretical and practical foundations for the formal and objective observation of a product. One of the most used methods is the heuristic evaluation, a term coined by Jakob Nielsen in 1989, that consists of using a set of usability heuristics to examine a product and analyze its degree of compliance. Due to the ever-growing use of Facebook by older adults, a heuristic evaluation of this application is carried out in this article, where principles of usability have been adapted to fit the profile of an older adult and the interaction with collaborative aspects and groupware functions that are characteristic of social networks. The results of this process of inspection will be of utmost importance to understand whether the current applications consider the older adult as a possible user, respecting principles of usability consistent with their profile.

Keywords: Human-Computer interaction; Usability; User experience; User-centered design; Groupware. 


\section{Introduction}

A worldwide phenomenon is taking place, which is the increasing and significant growth of adults over 65 years old in the population. The WHO, World Health Organization agrees that due to the extension of the estimated useful life, the index of people in the older adult age group is very high. It is believed that this community of adults will represent a $14 \%$ of the world population by 2025 and a $22 \%$ by 2050 , that is to say that they will be one older adult for every five persons worldwide, when nowadays there is one for every eight persons (WHO, 2014).

Now, how do these demographic changes affect the field of computer science and computer network? Will this population considered by the WHO to be in the process of active aging, become the next users of our future applications? Are our software products designed for older adults?

This study focuses its attention in the usability evaluation of one of the most popular social networks in recent times: Facebook, which many older adults have recently started or are about to start using (Oldmeadow et al., 2013). It represents a favorable field to analyze whether this application has a usable and accessible design for older adult users. Besides its popularity, it is a software that creates tendency and sets paradigms that can be adopted by other social networks and products.

The usability evaluation based on inspection methods allows for the analysis of the applications' interface in an objective and formal manner, through the eyes of $\mathrm{HCl}$ experts. It is important to learn about the applications in depth, to get acquainted before testing them with users, and also to consider beforehand whether or not they were designed with the older adult in mind.

In the case of the heuristic evaluation, which is the inspection method that will be carried out in this paper, the application is analyzed taking into account a set of recommendations, principles and guidelines, known as heuristics that establish how the interface should be designed. This allows the inspectors to be assisted in the process of research and detection of errors.

For this purpose, the heuristics applied in this article will be analyzed according to the user profile and the type of application, characterized by its collaborative and information sharing services. The results of the evaluation will be explained by showing the usability errors and the final conclusions.

\section{In search of specific usability heuristics according to elderly and social network interaction}

O Design Sprint é uma metodologia centrada no usuário, iterativa, prática e colaborThe ageing process can often result in elderly people experiencing multiple functional limitations like hearing loss, motor skill diminishment, vision decline or cognition effects (NIA, 2002). These limitations affect the way the interaction occurs, so specific usability guidelines must be considered by applications nowadays. The older adult requires that certain design considerations be taken into account in current applications to enjoy a quality-of-use interface. And this must happen with Facebook 
that older adults are adopting it lately.

But, how to choose the best set of usability and accessibility heuristics for applications that are web-based, with collaborative characteristics and that are appropriate for the interaction of the older adult? An appropriate and adaptive usability guidelines checklist must be developed from existing literacy.

In the first place, it is worth mentioning that in a groupware, the dialogue between user and computer is still present. Therefore, the most popular usability recommendations for single user interaction are still valid and will be contemplated in the set of heuristics.

However, several recommendations for groupware were taken into account in the evaluation. Primarily those that deal with the issue of concurrency from the perspective of the social interaction were there are concurrent activities from the members of the group, and simultaneous and multiple entries to a shared application (Hewitt and Gilbert, 1993). For the specific case of awareness, there are three important aspects of groupware that should be analyzed: what information should be gathered and distributed, how the information should be presented to the group and when the information should be shown so as to be useful (Gutwin and Greenberg, 2016).

In this regard, combining the contributions of the most recognized authors in the field of usability in the different application areas and always taking into account the older adult, a comprehensive process of selection and integration of the most important recommendations and design principles proposed by them was developed in the area of usability in general, web usability and accessibility, specific usability for older adults and usability in groupware.

The set of heuristics that were built taking into consideration the older adult, were the result of the consideration of the following contributions in usability:

- Jakob Nielsen's contributions for usability heuristics (Nielsen et al., 1993);

- Hassan Montero and Fernandez's contributions, specific for web usability (Hassan et.al, 2003);

- Adults usability checklist of NIA, National Institute of Aging (NIA, 2002);

- W3C accessibility recommendations for older users (W3C, 2008);

- Johnson and Finn's Design Guideline for Older Adults (Finn et.al, 2014);

- Gutwin and Greenberg's specific recommendations for groupware (2016), as well as Hewitt and Gilbert's (1993).

Among all of them, the most appropriate ones were analyzed, selected and refined for the case study regarding elderly and groupware interaction. If we would like to examine an application that has mostly enquiry forms and widgets, we should find or develop a set of heuristics that is appropriate for such interactive components. In this particular case, since we are studying an specific collaborative web application and considering the profile of the older adult, we proceeded to analyze and adapt the recommendations that will be used to carry out the heuristic evaluation.

In this sense, certain processes of transformation and intervention were carried 
out which involved the following activities:

Selection Process. From each source of recommendations provided by the well-known authors mentioned above, a set of guidelines was selected according to the interface type of the applications to be studied, dismissing those that do not apply in this case. For example, the usability recommendations for menus, radio buttons or check boxes were discharged because they are not predominant components in the user interfaces of the web applications that are the focus of our study.

Unification Process. Principles have been combined from several sources to make new ones. For example, Nielsen states that it is necessary to provide semantic feedback to distinguish the state of the system; Hassan Montero remarks that there must be a clear page structure; and on groupware, Hewitt states that the local area must be distinguished from the global one. From these contributions, a new principle was elaborated that establishes that there should be a clear design providing explicit feedback both on the local context as well as the shared one.

Synthesis Process. Several guidelines made it possible to form and constitute one, taking into account the more specific one. For example, Nielsen states that a clear, distinguishable font must be provided, whereas the NIA recommendations suggest that the font size should be 12 or higher, Times New Roman font type, and that text should be expressed in an active voice. The latter being more specific than the previous one, was the one that was included.

Integration and Categorization Processes. The final adaptive heuristics were grouped and integrated into nine different categories which allowed for a better organization of the process of inspection and examination.

As the result of this adaptation process of the most important design principles, a set of 65 usability adaptive rules were derived. They were classified in order of priority.

Priority in this case is based and proposed analyzing how much said recommendations affect the gulf of execution and evaluation in the interaction of the older adult with the application. According to Donald Norman, the gulf of execution is the cost that the user has in order to carry out his intentions in the system, while the gulf of evaluation is the cost that the user has in order to interpret the status of the system after the action [Hutchins et al., 1985]. A well-designed interface for older adults that respects usability guidelines should minimize both gulfs or distances in the interaction.

Each guideline according to its priority has a gradual rating of 1 to 3 , in case it is complied. The following table describes these priorities:

Table 1: Priorities of Usability Heuristics

\begin{tabular}{ccc}
\hline PRIORITY & DESCRIPTION & $\begin{array}{c}\text { USABILITY } \\
\text { RATING IN CASE } \\
\text { OF COMPUANCE }\end{array}$ \\
\hline Priority 1 & $\begin{array}{c}\text { It is of high priority } \\
\text { It must be complied }\end{array}$ & High 3 points \\
& $\begin{array}{l}\text { Its non-compliance can prevent the completion of a } \\
\text { task or result in the misinterpretation of the system. }\end{array}$ \\
\hline
\end{tabular}




\begin{tabular}{|c|c|c|}
\hline Priority 2 & $\begin{array}{l}\text { It is of medium priority. } \\
\text { It should be complied. } \\
\text { Its non-compliance can hinder the completion of a } \\
\text { task or affect the correct interpretation of the } \\
\text { system. }\end{array}$ & $\begin{array}{c}\text { Medium } 2 \\
\text { points }\end{array}$ \\
\hline Priority 3 & $\begin{array}{l}\text { It is of low priority. } \\
\text { It could be complied. } \\
\text { Its non-compliance does not affect the completion } \\
\text { of a task or the interpretation of the system. }\end{array}$ & Low 1 point \\
\hline
\end{tabular}

Source: Elaborated by the authors according the research done

In the next section, the evaluation inspection will be explained in detail.

\section{The heuristic evaluation applied to Facebook}

The set of heuristics compiled in the previous section was applied in the usability inspection study conducted on Facebook. The application was explored in search for the compliance of 65 adapted recommendations.

The usability analysis is organized into the nine categories that will be explained in detail in the next sections. The evaluation results for each category are shown in tables. In each table it will be listed the selected heuristics with the priority that was assigned to it, the source(s) where such recommendation was taken from, whether it was complied with or not in Facebook and the usability problems found.

\subsection{Heuristic analysis regarding presentation component}

Table 2 shows the results of the heuristic evaluation regarding display features considering that the user interface design should guarantee to elderly the clear perception of the information that is being transmitted.

Table 2: Usability heuristic evaluation regarding presentation component

\begin{tabular}{|c|c|}
\hline HEURISTIC & COMPLIANCE EVALUATION \\
\hline $\begin{array}{c}\text { Priority: II } \\
\text { Source: NIA } \\
\text { San Serif typography. Size bigger than } \\
12 .\end{array}$ & $\begin{array}{c}\text { Non compliance. } \\
\text { Reduced size typography is used, from } 8 \text { to } 12 . \\
\text { Not Sans Serif (Figure 1). }\end{array}$ \\
\hline $\begin{array}{l}\text { Priority: I } \\
\text { Sources: NIA; W3C; Finn et al. } \\
\text { Adequate use of colors, Good contrast } \\
\text { between background and foreground. } \\
\text { Avoid the use of yellowish and very } \\
\text { dark colors together. }\end{array}$ & $\begin{array}{l}\text { Non compliance. } \\
\text { It does not pass the Juicy Studio contrast validator. } \\
\text { It features } 28 \text { contrast problems in luminosity, } 63 \text { in } \\
\text { brightness and } 161 \text { in colors (Figure 2) }\end{array}$ \\
\hline $\begin{array}{c}\text { Priority: I } \\
\text { Source: W3C } \\
\text { Do not use color to denote information } \\
\text { or avoid expressing information within } \\
\text { an image. }\end{array}$ & $\begin{array}{l}\text { Non compliance. } \\
\text { When removing images, important icons disappear } \\
\text { from the upper bar such as the Notification, } \\
\text { Message, Configuration and even the Log Out } \\
\text { icons. The Post menu disappears (Figure 3). }\end{array}$ \\
\hline $\begin{array}{l}\text { Priority: II } \\
\text { Sources: Nielsen; Hassan et.al, } \\
\text { Short block contents and with meaning. } \\
\text { One paragraph = one idea. }\end{array}$ & $\begin{array}{l}\text { Compliance. } \\
\text { Generally, there are paragraphs that extend to no } \\
\text { longer than } 4 \text { lines. }\end{array}$ \\
\hline
\end{tabular}




\begin{tabular}{|c|c|}
\hline $\begin{array}{c}\text { Priority: I } \\
\text { Sources: Hassan et al.; W3C; Finn et } \\
\text { al. } \\
\text { Correct use of titles and headings, } \\
\text { Highlight section titles and page } \\
\text { elements. }\end{array}$ & $\begin{array}{l}\text { Non compliance. } \\
\text { Sections and panels were noticed without titles or } \\
\text { headings that provide the older adult with greater } \\
\text { clarity (Figure 4). }\end{array}$ \\
\hline $\begin{array}{c}\text { Priority: II } \\
\text { Sources: NIA; Hassan et al. } \\
\text { Avoid visual noise. Do not overuse } \\
\text { images, marquees, signs, texts in all } \\
\text { caps or in bold. }\end{array}$ & $\begin{array}{l}\text { Non compliance. } \\
\text { There are advertisements and game panels that } \\
\text { cannot be removed and distract the user's } \\
\text { attention, since it does not represent the main } \\
\text { content of the website. } \\
\text { The profile page has up to } 4 \text { columns with various } \\
\text { information that include activities, information and } \\
\text { multimedia content, and this represents a } \\
\text { significant visual burden (Figure 1). }\end{array}$ \\
\hline $\begin{array}{c}\text { Priority: II } \\
\text { Sources: Nielsen; NIA } \\
\text { Speak the user's language: positive, } \\
\text { clear and simple. Avoid foreign, } \\
\text { technical language. Use active voice. }\end{array}$ & $\begin{array}{l}\text { Non compliance. } \\
\text { Language is usually understandable. No technical } \\
\text { or English words are used except for "cookies", } \\
\text { "poke" or "plugins". It does not use active voice. }\end{array}$ \\
\hline $\begin{array}{c}\text { Priority: I } \\
\text { Sources: NIA; Nielsen } \\
\text { Avoid overusing abbreviations, types, } \\
\text { incorrect our outdated information. }\end{array}$ & $\begin{array}{l}\text { Compliance. } \\
\text { This error is not found. }\end{array}$ \\
\hline $\begin{array}{c}\text { Priority: III } \\
\text { Source: NIA } \\
\text { Good presentation in printable format. }\end{array}$ & $\begin{array}{l}\text { Non compliance. } \\
\text { The printable format does not provide a good } \\
\text { presentation. Some elements are missing, dashed } \\
\text { or overlapped. The presentation appears to be } \\
\text { disorganized (Figure 5). }\end{array}$ \\
\hline
\end{tabular}

Source: Elaborated by the authors according the research done

\section{The figures mentioned in the Table 1 are:}

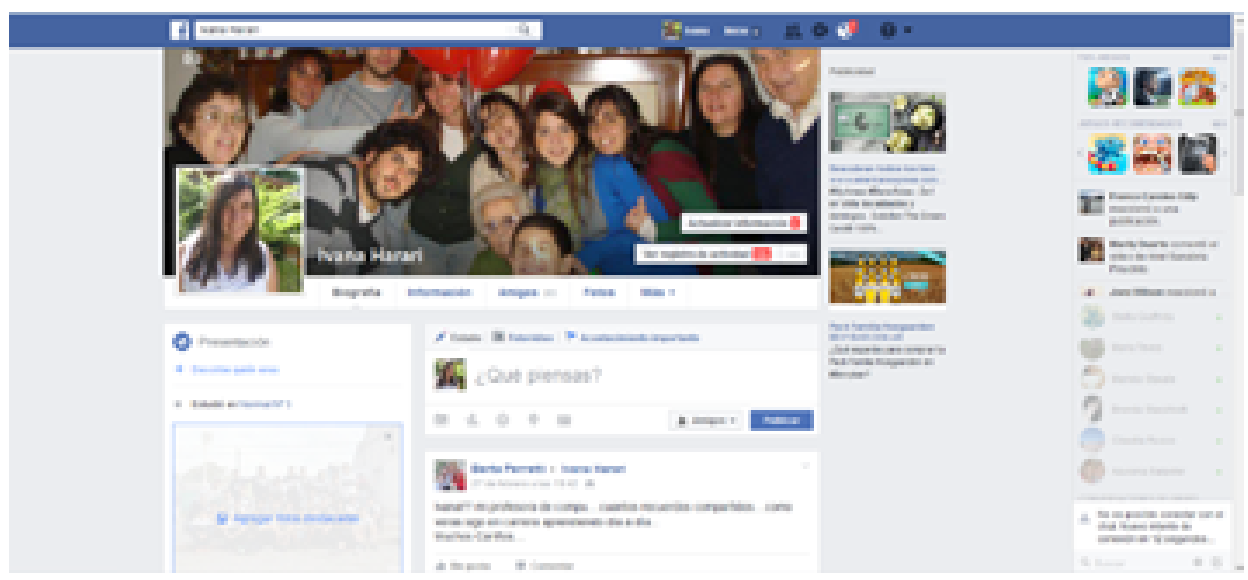

Figure 1: Small fonts used in Facebook

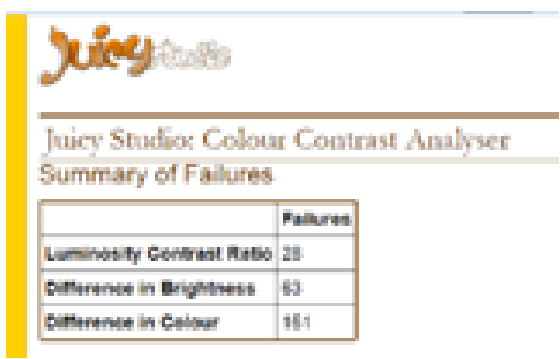

Figure 2: Summary of failures in Facebook using Juicy Studio analyser 


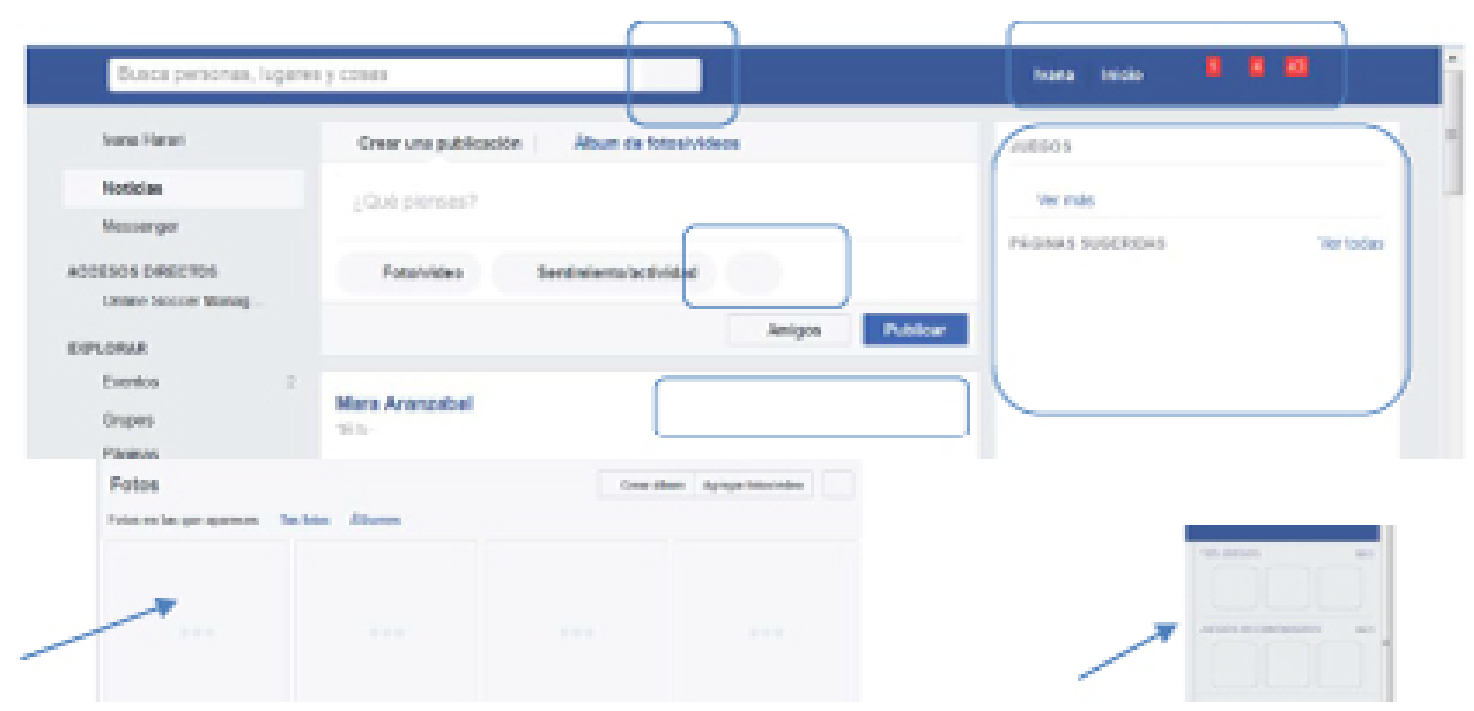

Figure 3: Without images same options became inaccessible

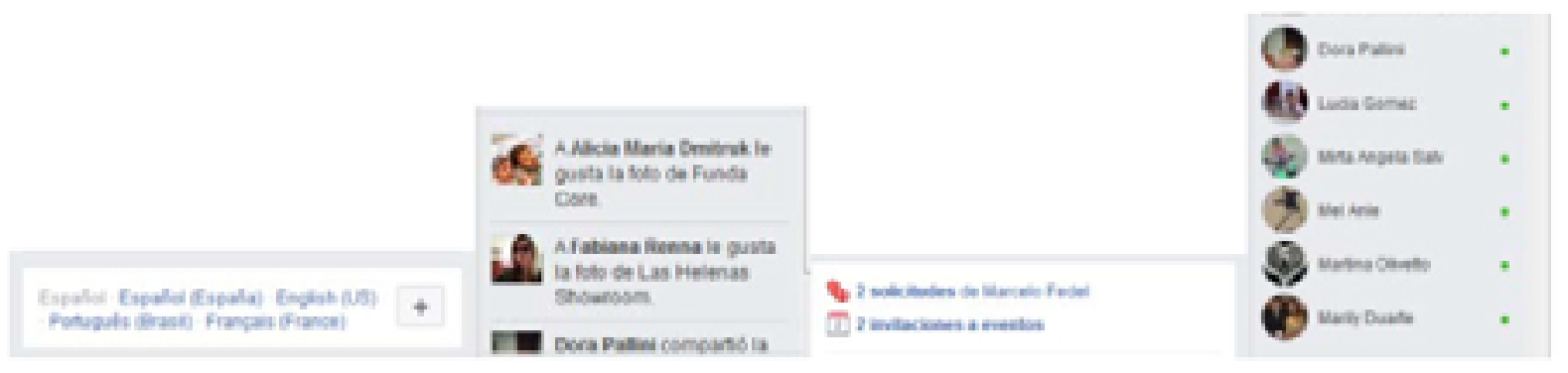

Figure 4: Important sections and panels without titles or headings

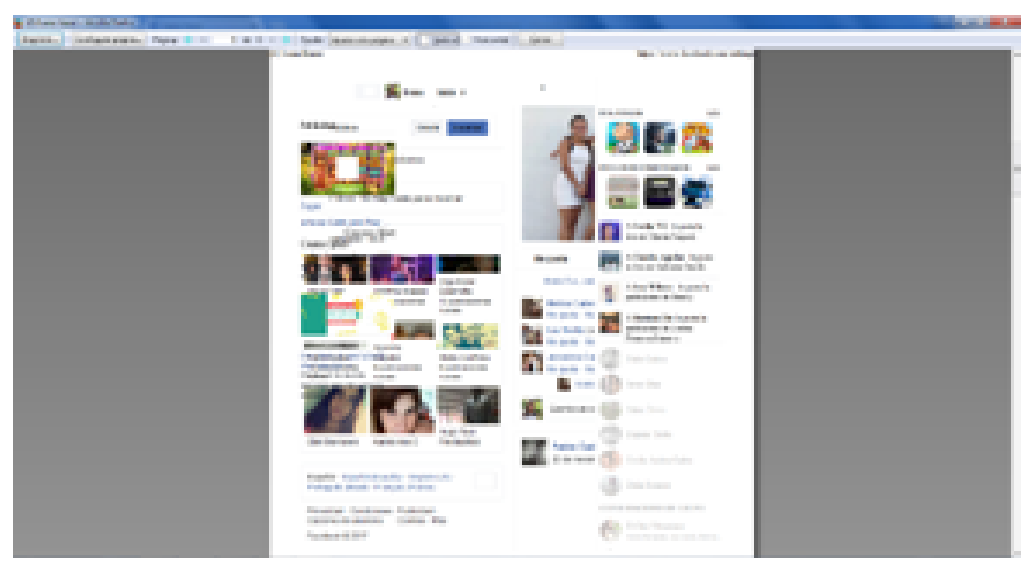

Figure 5: Bad web content presentation in printable format

\subsection{Heuristic evaluation about dialogue component}

Table 3 shows the results of the usability inspection regarding simple and flexible user-computer Interaction. The recommendations refined here point to the simplicity in the use of the application by elderly, as well as those that suggest that users should always have the control of the interaction. 


\begin{tabular}{|c|c|}
\hline HEURISTIC & COMPLIANCE EVALUATION \\
\hline $\begin{array}{l}\text { Priority: I } \\
\text { Sources: Nielsen; NIA } \\
\text { The control of the dialogue must be } \\
\text { simple and directed by the user. }\end{array}$ & $\begin{array}{l}\text { Non compliance. } \\
\text { In the Update Status dialogue box, the different } \\
\text { options such as Feeling/Activity are opened in } \\
\text { overlapping menus and they are difficult to close. } \\
\text { The See More option can be activated but when it } \\
\text { unfolds, the See Less option is not found and the } \\
\text { panel cannot be closed (Figure 6). }\end{array}$ \\
\hline $\begin{array}{l}\text { Priority: II } \\
\text { Source: NIA } \\
\text { One-click interaction should prevail. } \\
\text { Avoid double clicking and Dragging }\end{array}$ & $\begin{array}{c}\text { Everything is done with one click. No significant } \\
\text { dragging. Therefore this recommendation is } \\
\text { complied with. }\end{array}$ \\
\hline $\begin{array}{l}\text { Priority: III } \\
\text { Source: Nielsen; Hassan et al. } \\
\text { Good search system; visible, efficient } \\
\text { and provides advanced search. }\end{array}$ & $\begin{array}{l}\text { There are segments that feature a lot of } \\
\text { information and do not have a search system. } \\
\text { There are no searches in posts, people that posted } \\
\text { or invitations to events, among others. }\end{array}$ \\
\hline $\begin{array}{l}\text { Priority: I } \\
\text { Source: W3C } \\
\text { Allow adequate interaction all with } \\
\text { keyboard or all with mouse. Direct } \\
\text { access to the main content. }\end{array}$ & $\begin{array}{l}\text { There are problems of focus in the interaction with } \\
\text { keyboard. When interacting with the Tab key, the } \\
\text { dialogue window remains open and continues on } \\
\text { the page below without the respective focus. There } \\
\text { are icons that when in focus cannot be clicked on } \\
\text { with neither the Enter or Tab key nor with the } \\
\text { spacebar. It does not have access keys (Figure 7). } \\
\text { With the exclusive interaction of the mouse, it } \\
\text { works correctly. Visual keyboard was used when } \\
\text { the use of the keyboard was required. }\end{array}$ \\
\hline $\begin{array}{c}\text { Priority: II } \\
\text { Sources: Nielsen; Finn et al. } \\
\text { Increase flexibility of data entry. } \\
\text { Anticipate common errors. Provide } \\
\text { mechanisms for automatic correction. }\end{array}$ & $\begin{array}{l}\text { No flexible dialogue or strategies for error } \\
\text { anticipation. No automatic correction. }\end{array}$ \\
\hline $\begin{array}{c}\text { Priority: I } \\
\text { Source: Nielsen } \\
\text { Provide evident outlets to each } \\
\text { operation, task or transaction. Allow the } \\
\text { possibility to undo actions or exit } \\
\text { undesired situations. }\end{array}$ & $\begin{array}{c}\text { Facebook's log out button is not evident. It can } \\
\text { only be found when clicking a barely noticeable } \\
\text { arrow. } \\
\text { Posts are not allowed to be undone. } \\
\text { If a person is accidentally blocked or reported, it } \\
\text { does not offer the option to undo said action. } \\
\text { Some windows offer the possibility and option to } \\
\text { close them but others do not. }\end{array}$ \\
\hline $\begin{array}{c}\text { Priority: III } \\
\text { Source: Hassan et al. } \\
\text { Website, image and video load time } \\
\text { speed. Show progress or indicate } \\
\text { estimated load time. }\end{array}$ & $\begin{array}{l}\text { Delays of certain actions are not previously } \\
\text { indicated. The display of certain progress does not } \\
\text { include information of interest such percentage of } \\
\text { progress or remaining time (Figure } 8 \text { ). }\end{array}$ \\
\hline $\begin{array}{c}\text { Priority: I } \\
\text { Sources: W3C; Hassan et al. } \\
\text { Operable on different browsers, } \\
\text { with/without plug-ins, with/without } \\
\text { JavaScript, with/without style sheets. }\end{array}$ & $\begin{array}{l}\text { It exhibits problems without JavaScript. Many } \\
\text { important functions cannot be accessed. For } \\
\text { example, the menu to change the privacy settings } \\
\text { of a post, written accents or drop-down menus stop } \\
\text { working without Javascript (Figure 9). } \\
\text { Without style sheets everything overlaps. } \\
\text { It features problems when accessing with browsers } \\
\text { that do not support these technologies (Figure 10). }\end{array}$ \\
\hline $\begin{array}{c}\text { Priority: I } \\
\text { Sources: W3C, Finn et al. } \\
\text { Allow the use of assistive technologies } \\
\text { or provide them. } \\
\text { Priority: I } \\
\text { Sources: W3C; Finn et al. } \\
\text { Do not pressure to finish a task or } \\
\text { action in a certain period of time. }\end{array}$ & $\begin{array}{l}\text { It allows the use of virtual keyboards (Figure 11). } \\
\text { It allows the use of screen readers. }\end{array}$ \\
\hline
\end{tabular}


Adapting usability heuristics to evaluate

Facebook according to elderly

\begin{tabular}{|c|c|}
\hline $\begin{array}{l}\text { Priority: III } \\
\text { Source; Nielsen } \\
\text { Provide shortcuts to speed up the } \\
\text { interaction with the system. }\end{array}$ & $\begin{array}{l}\text { It does not offer the possibility to define or set } \\
\text { shortcuts for the users that have a greater } \\
\text { command of the application. }\end{array}$ \\
\hline $\begin{array}{l}\text { Priority: II } \\
\text { Source: Hassan et al. } \\
\text { Configuration and management of } \\
\text { preferences and display aspects. }\end{array}$ & $\begin{array}{l}\text { It does not allow the configuration of preferences at } \\
\text { the display level. There are pages with information } \\
\text { in widgets format that cannot be listed or filtered. }\end{array}$ \\
\hline
\end{tabular}

Source: Elaborated by the authors according the research done

\section{The figures for this category are:}

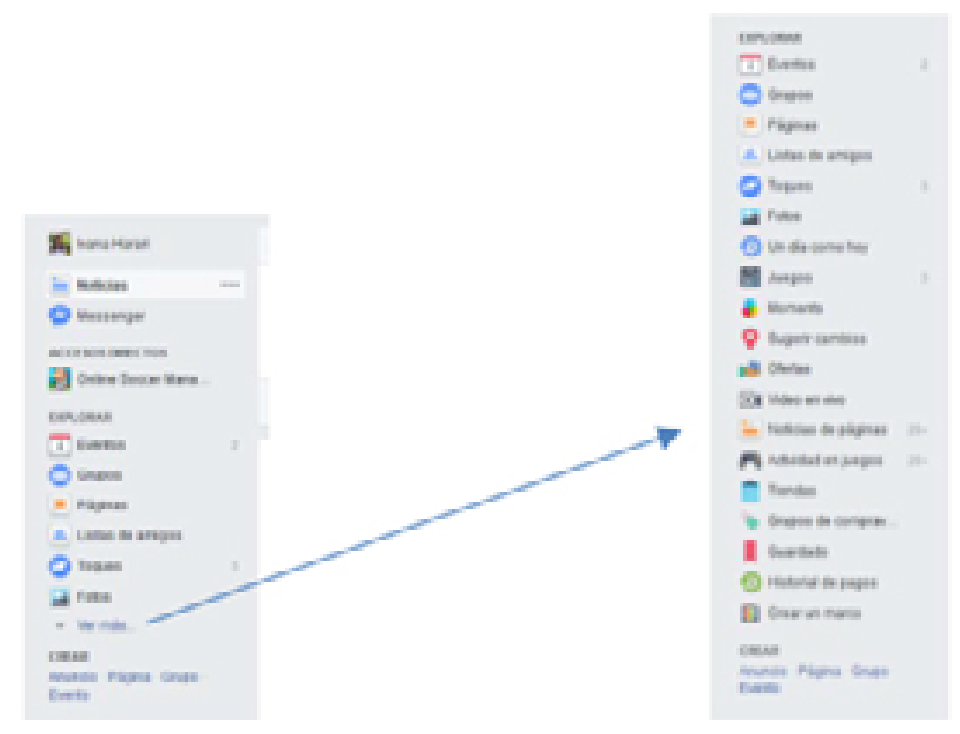

Figure 6: See More option but without See Less option to close the expanded

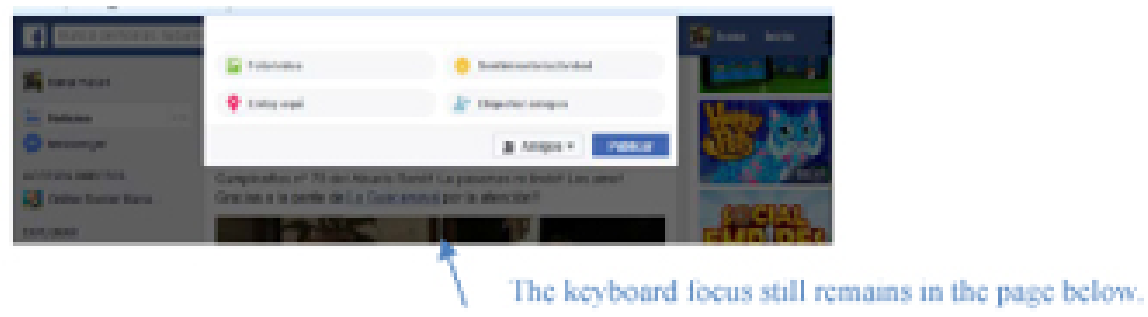

Figure 7: Focus problems in the interaction with keyboard
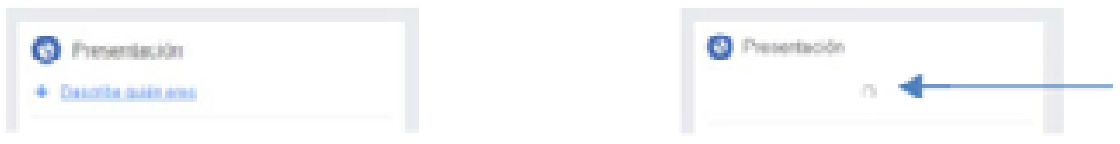

Figure 8: No progress or estimated load time shown

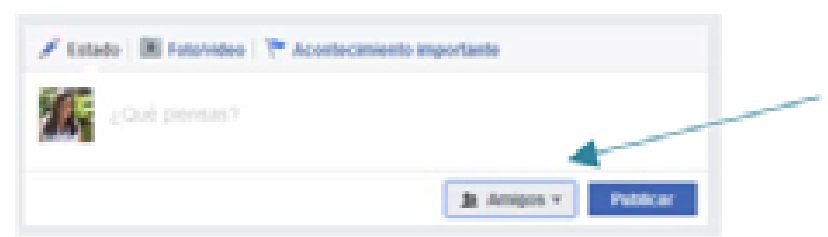

Figure 9: Buttons do not work with Javascript disabled or an error page appears 


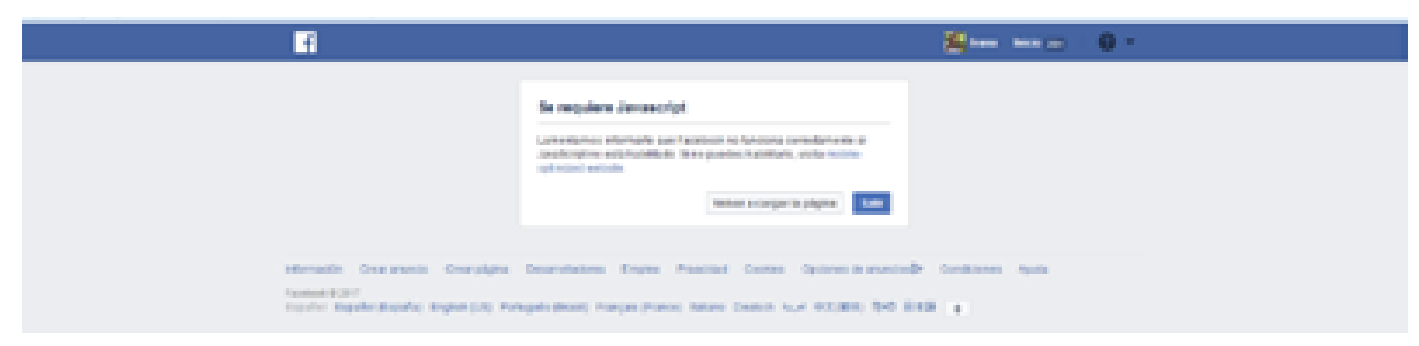

Figure 9: Buttons do not work with Javascript disabled or an error page appears

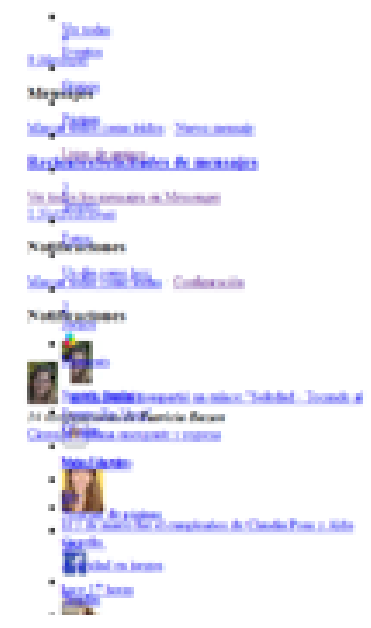

Figure 10: Problems in the page when CSS is disabled

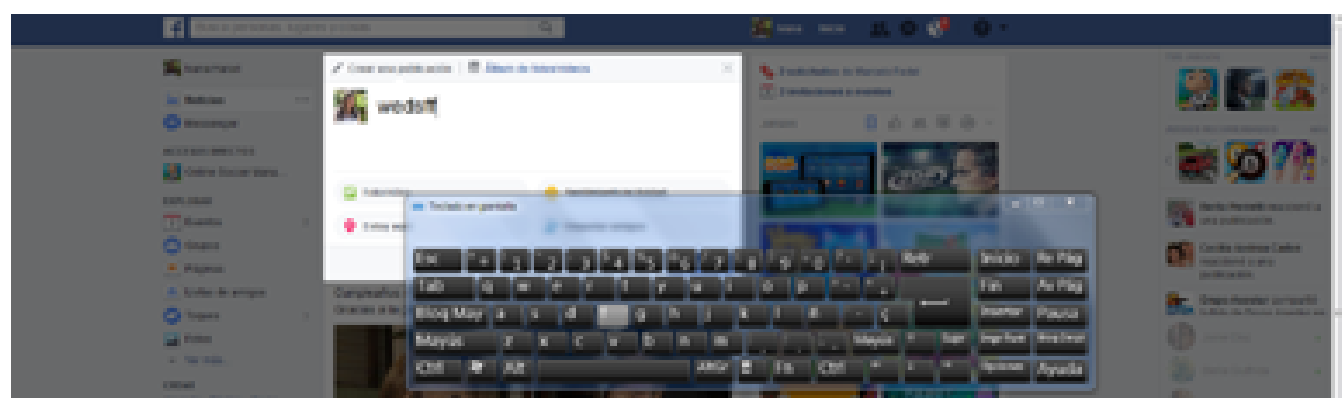

Figure 11: With virtual keyboards Facebook functions correctely

\subsection{Heuristic evaluation regarding site structure and content}

On this point 10 heuristics were compiled and refined to ensure that the application is built under a logical and simple structure of information and content appropriate for older users. They include clear content sections, good content balance and distribution, and adequate level of information without saturation, absence or lack of information.

The results of the usability analysis regarding website structure and content is shown in Table 4. 


\begin{tabular}{|c|c|}
\hline HEURISTIC & COMPLIANCE EVALUATION \\
\hline $\begin{array}{c}\text { Priority: II } \\
\text { Sources: NIA; Hassan et al. } \\
\text { Content layout that is clear and } \\
\text { organized through a logical } \\
\text { identification of areas by title, main } \\
\text { content, navigation and } \\
\text { messages. }\end{array}$ & $\begin{array}{l}\text { The layout is designed in panels and sections but its } \\
\text { general visual aspect is disorganized and inconsistent. } \\
\text { In Homepage, Profile and Setting pages, the menu } \\
\text { option are at the left side but in Messenger page, a chat } \\
\text { panel is there and the menu option is positioned at the } \\
\text { right side. }\end{array}$ \\
\hline
\end{tabular}

Priority: I

Sources: NIA; Nielsen; Hassan et al.

Prioritize contents. Distribute information appropriately. Do not mix relevant and irrelevant information.

Priority: II

Source: NIA

Balance extended pages. Offer indexes or search per page.

Non compliance.

Relevant information is usually in the center of the page but in some other cases, important information is found in isolated and secondary places. For example, between two important sections, such as the publication section and the chat section, there are areas assigned to publicity (Figure 1).

Non compliance.

There are extended pages that take up several scroll pages and do not have indexes or a search option. Old posts can only be accessed by scrolling down. Groups,

Pages, Notifications and News do not have a search system (Figure 12); while Friends, Messages and Photos do.

\section{Priority: I}

Sources: NIA; Nielsen; Hassan et al.

Provide an adequate degree of information for beginners as well as experts. Avoid information overload or lack of information. Priority: II Source: Hassan et al. Good impression of the home page that it must include a description of the site.

\section{Priority: II}

Source: Hassan et al. Always show identity of entity or logo.

Priority: III Sources: NIA; Finn et al. Provide a map of the site, contact information, client support, etch.

\section{Priority: II}

Source: Hassan et al. Do not use browser functions such as printing, saving, zooming, etch.

Priority: I

Sources: NIA; Nielsen; Hassan et al.

Provide help and assistance mechanisms at the page, transaction and site levels.
Information is intended for people with computer skills. No information is provided as to how to operate Facebook. There is not a contextual help.

There is an overload of information in the Quick Help section but it is not intended for beginners (Figure 13). There is confusing language in help text (Figure 14). Non compliance.

It does not include a description of the site.

There are functions that open in a new tab and do not have access to the home page.

\section{Non compliance.}

There are functions such as Settings-Ads or Advertising on Facebook that open in a new tab and do not have the frame, the logo or the other elements of the site to contextualize the user (Figure 15).

Non compliance.

No presence of a site map was found. Neither was there evidence of any contact information such as fax, phone number, e-mail or postal mail.

Non compliance,

The application does not offer functions such as print, save and zoom so it is necessary to use the web navigator's.

Non compliance.

Facebook does not bring component or section helps. Chat section, Messenger page have not help option.

The More Information option in Settings is contextual but it is perceived as if it was not because it changes the visual aspect completely.
Priority: II

Source: NIA

Include glossary of terms
Compliance.

Within the Help section, the concept of terminology is explained partially and implicitly. 
The usability errors mentioned in this section, are shown in the next figures.

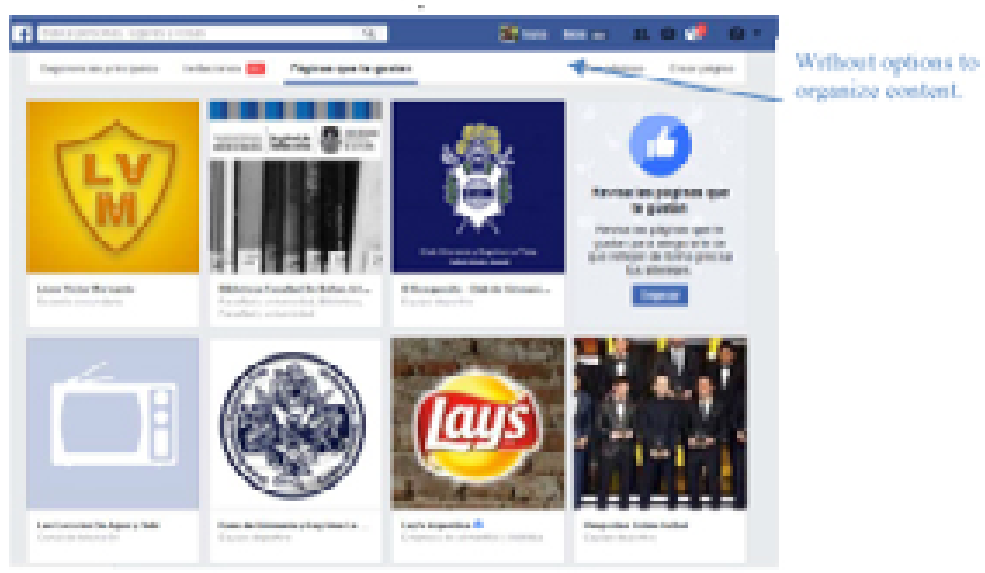

Figure 12: panels with a lot of information without filtering and organization functions

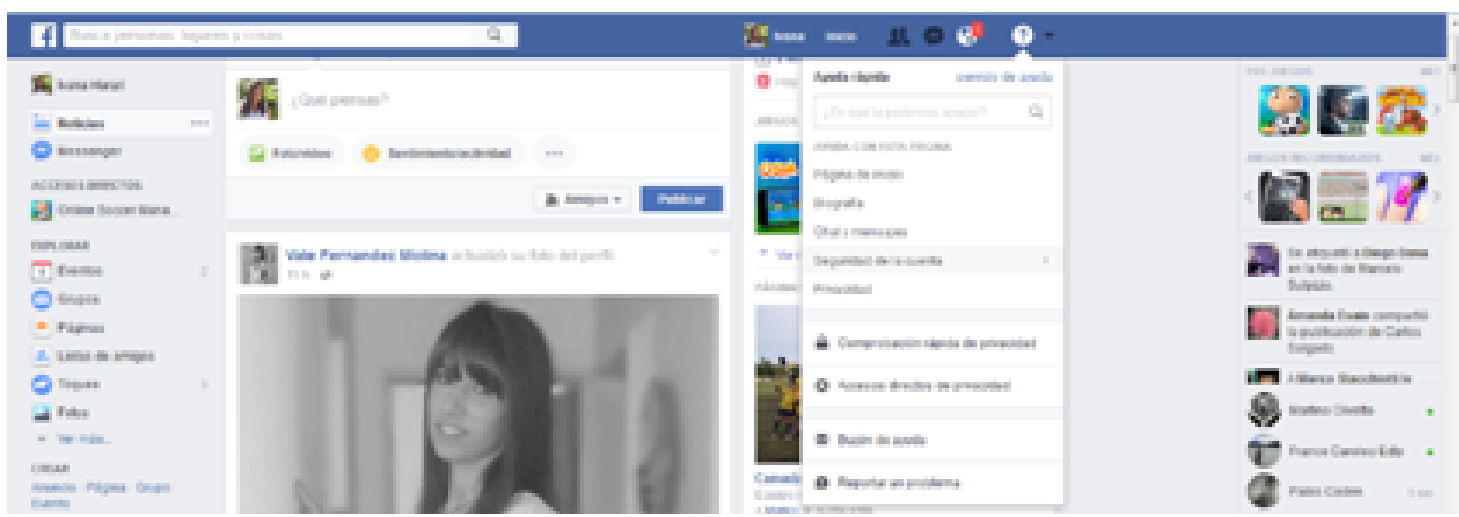

Figure 13: Quick Help accessed from Profile page without information according to that context

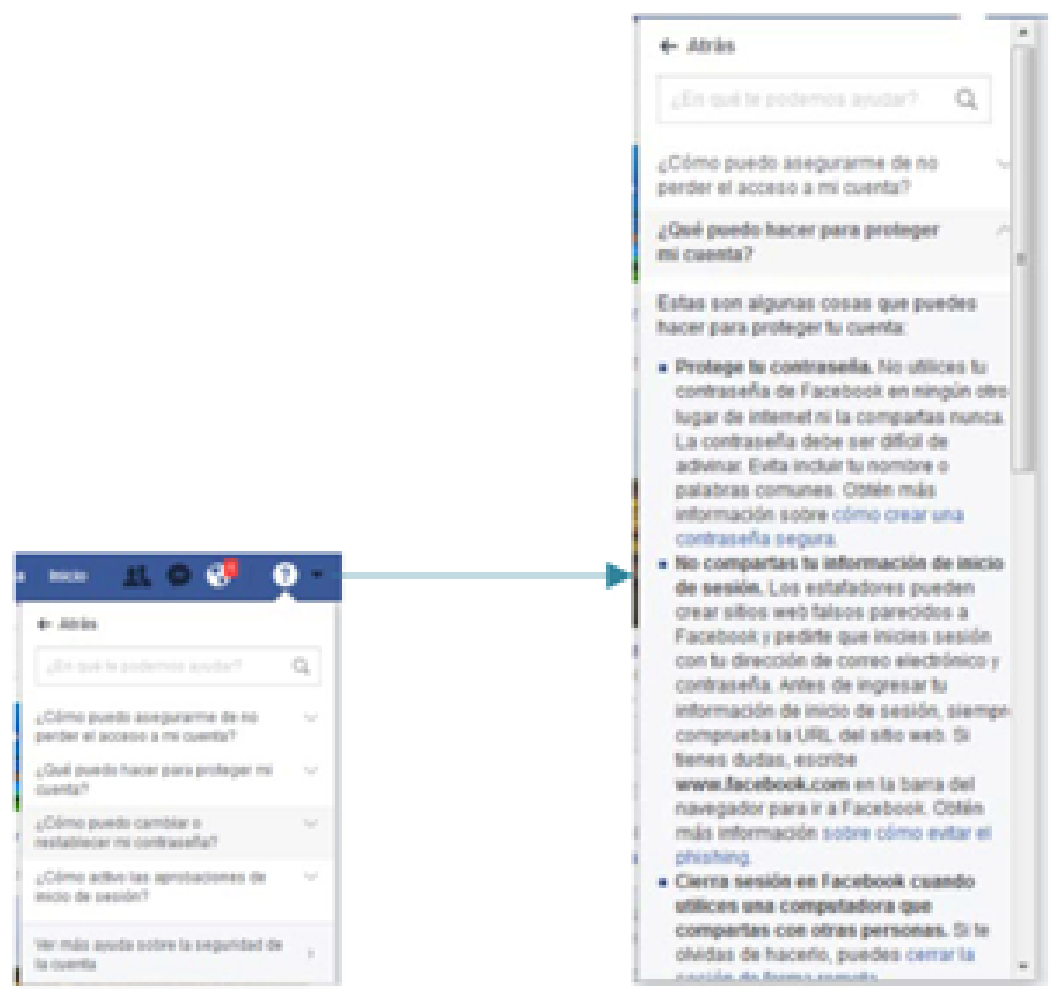

Figure 14: Help of "How to protect a password" contains much confusing information 
Adapting usability heuristics to evaluate

Facebook according to elderly

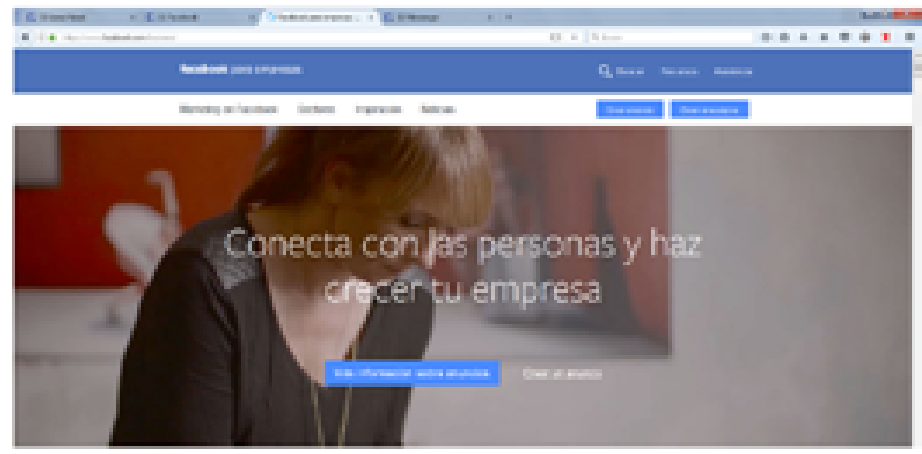

Figure 15: Framework options that opens a new tab without a logo or other elements of the application to contextualize the user

Table 5: Usability evaluation considering visual components and multimedia principles

\begin{tabular}{|c|c|}
\hline HEURISTIC & COMPLIANCE EVALUATION \\
\hline $\begin{array}{c}\text { Priority: I } \\
\text { Sources: Nielsen; W3C; Finn et al. } \\
\text { Well form design. Identify required items. } \\
\text { Each box must have a title. Divide by } \\
\text { sections and groups. Same with dialogue } \\
\text { windows. }\end{array}$ & $\begin{array}{l}\text { Compliance. } \\
\text { Sometimes it does not specify which information } \\
\text { is obligatory and which one is not. But generally. it } \\
\text { provides well form design. }\end{array}$ \\
\hline $\begin{array}{c}\text { Priority: I } \\
\text { Sources: NIA; Hassan et al. } \\
\text { Use of simple and well-organized menus } \\
\text { with an eetabliehed logic. } \\
\text { Avoid the excessive use of drop-down } \\
\text { and contextual menus. }\end{array}$ & $\begin{array}{l}\text { Non compliance. } \\
\text { There are menus that unfold at a scroll and others } \\
\text { that overlap like the upper bar in Messages } \\
\text { (Figure 16). }\end{array}$ \\
\hline $\begin{array}{l}\text { Priority: II } \\
\text { Sources: W3C; Hassan et al. } \\
\text { Provide accessible tables, videos, } \\
\text { graphics, carrousels or multimedia. }\end{array}$ & $\begin{array}{l}\text { Non compliance. } \\
\text { There are many functional images and icons } \\
\text { without alternative text. It does not provide } \\
\text { responsive design or adaptive design (Figure 17). }\end{array}$ \\
\hline $\begin{array}{l}\text { Prionity: I } \\
\text { Sources: NIA; W3C; Finn et al. } \\
\text { Textual alternative for all the means of } \\
\text { communication. }\end{array}$ & $\begin{array}{l}\text { Non compliance. } \\
\text { Multimedia content from the application such as } \\
\text { videos without subtitles and images without } \\
\text { alternative text were found. }\end{array}$ \\
\hline
\end{tabular}

Source: Elaborated by the authors according the research done

\section{The figures mentioned here are:}

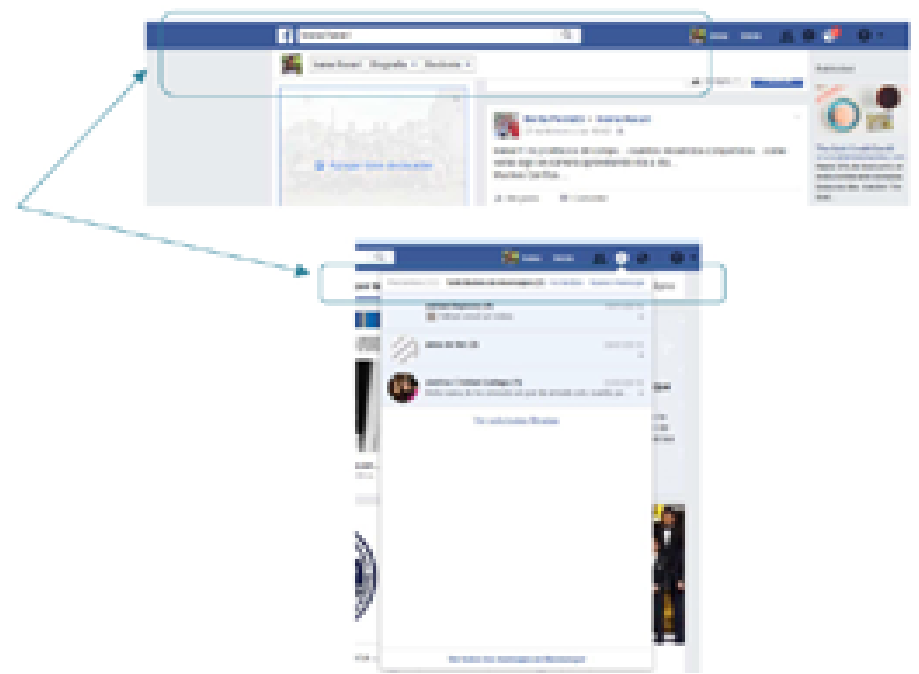

Figure 16: Menu bar that disappears at a scroll and others that overlap 


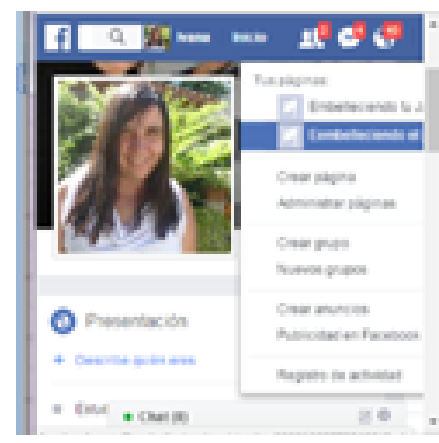

Figure 17: Facebook does not provide responsive design

\subsection{Heuristic evaluation regarding site structure and content}

The usability evaluation regarding minimizing user memory load is shown in the Table 6 where 4 principles were formulated. The elderly user does not have to remember where he is, and what were his last actions in the application. Adult users do not have to remember complicated syntactic mechanisms to perform a task. Neither, they do not have to remember data required by the system that can be recovered from the same system.

Table 6: Usability evaluation regarding minimizing user memory load

\begin{tabular}{|c|c|}
\hline HEURISTIC & COMPLIANCE EVALUATION \\
\hline $\begin{array}{l}\text { Priority: I } \\
\text { Sources: Nielsen; NIA } \\
\text { Provide information of the context, } \\
\text { navigation and current session. Provide } \\
\text { breadcrumbs correctly. }\end{array}$ & $\begin{array}{c}\text { Non compliance. } \\
\text { It does not feature breadcrumbs. } \\
\text { Some pages are visually colorful, with many } \\
\text { images and panels, but without the corresponding } \\
\text { headings so the user does not know where he or } \\
\text { she is located. }\end{array}$ \\
\hline $\begin{array}{l}\text { Priority: I } \\
\text { Sources: Nielsen; Hassan et al. } \\
\text { Display the system's admissible input } \\
\text { range. Examples. Input format. Avoid } \\
\text { typing information for prevention. }\end{array}$ & $\begin{array}{l}\text { Compliance. } \\
\text { The templates have a possible input range and } \\
\text { format examples. }\end{array}$ \\
\hline $\begin{array}{l}\text { Priority: II } \\
\text { Sources: NIA; Finn et al. } \\
\text { Show step by step. Give clear and } \\
\text { numbered instructions in every step. } \\
\text { Facilitate the retention of information } \\
\text { and learning. }\end{array}$ & $\begin{array}{l}\text { Non compliance. } \\
\text { No step-by-step instructions are given, which are } \\
\text { necessary for transactions such as Create Album } \\
\text { and Add Photos or in Notification Filters, among } \\
\text { others (Figure 18). No support is provided to } \\
\text { minimize the memorization of the user. }\end{array}$ \\
\hline $\begin{array}{l}\text { Priority: I } \\
\text { Sources: NIA; Finn et al.; Nielsen } \\
\text { Reduce the cognitive and memory load } \\
\text { to perform tasks. }\end{array}$ & $\begin{array}{l}\text { Non compliance. } \\
\text { There are confusing transactions such us the issue } \\
\text { of the ads that are dealt with differently in Settings } \\
\text { from the Homepage as well as from Advertising. } \\
\text { The same happens with Photos from Settings as } \\
\text { well as Homepage (Figure 19). } \\
\text { This results in an effort on the part of the user to } \\
\text { understand whether it is the same or a different } \\
\text { issue under the same term. }\end{array}$ \\
\hline
\end{tabular}


The figures corresponding to Table 5 are:
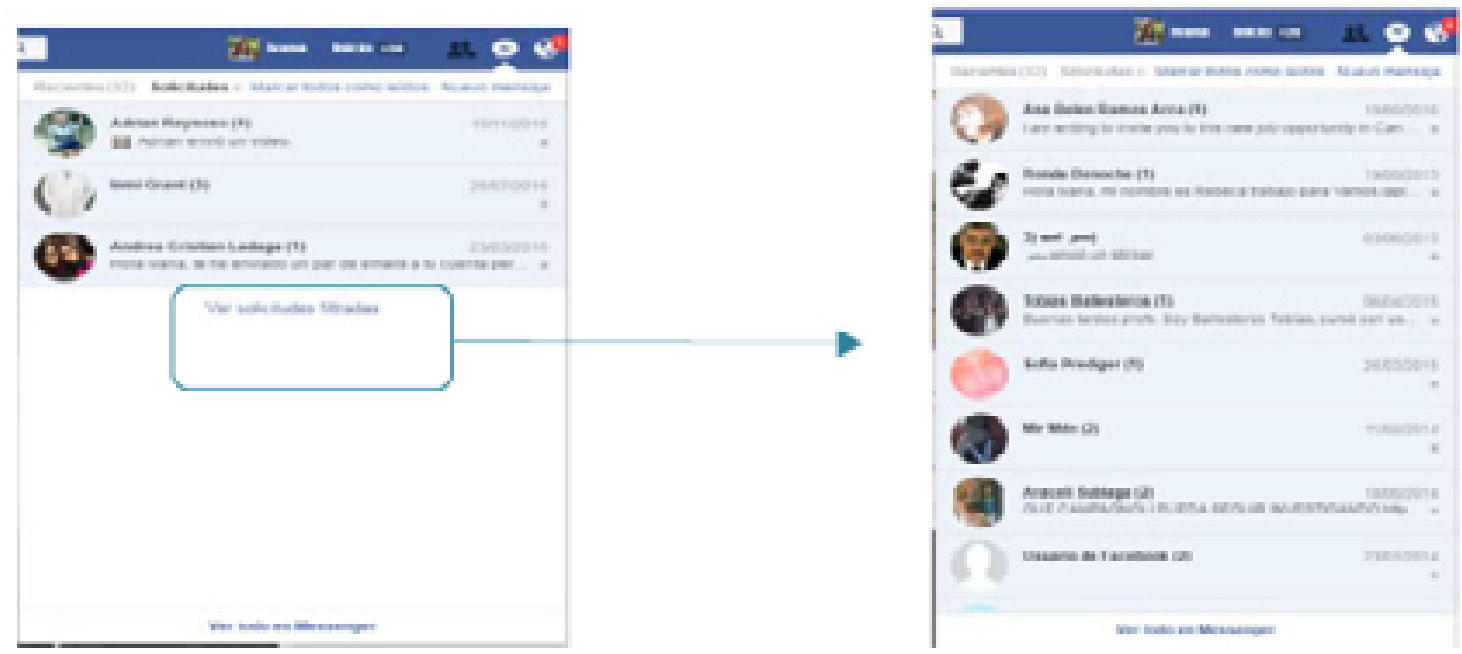

Figure 18: Example where no step-by-step instructions are given.

There is no information about how to filter message requests, the nor how to define and select the filtering criteria
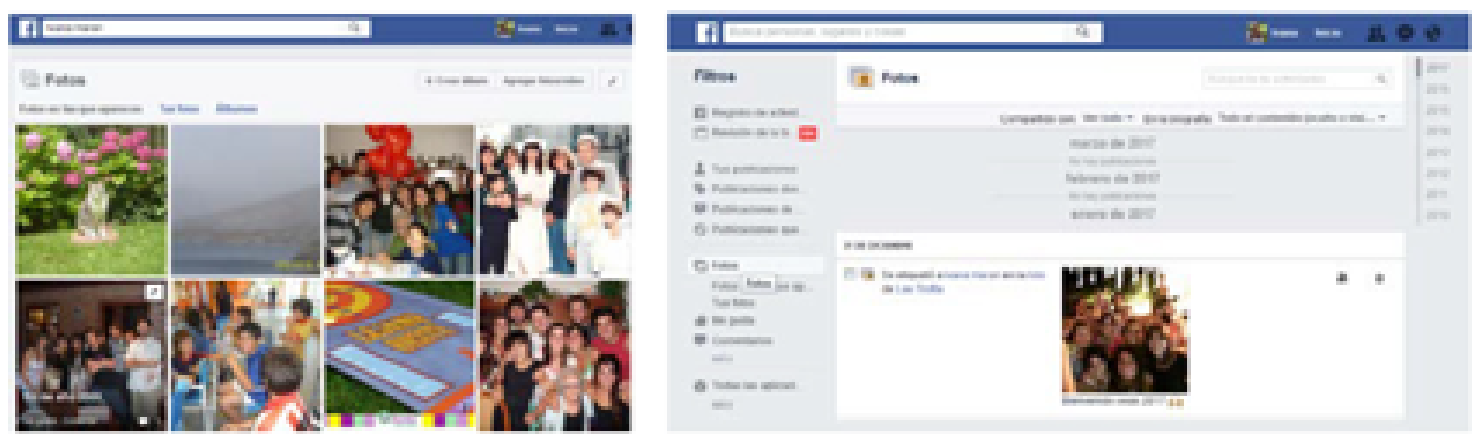

Figure 19: Confusing transactions or options that have the same name but are dealt in different manner

\subsection{Heuristic evaluation considering visual and terminological consistency}

The evaluation of usability regarding visual and terminological consistency is explained in Table 7. An effort must be made to not show/define the same information in different ways and vice versa, to not show/define different information in the same way, that would lead to unstable, confusing and operationally hampering situations.

Table 7: Heuristic evaluation according to visual and terminological consistency

\begin{tabular}{|c|c|}
\hline HEURISTIC & COMPLIANCE EVALUATION \\
\hline $\begin{array}{l}\text { Priority: I } \\
\text { Sources: Nielsen; Hassan et al.; Finn et } \\
\text { al. } \\
\text { There must be terminological } \\
\text { consistency. A unique syntactic } \\
\text { representation for the same concept or } \\
\text { semantic element. }\end{array}$ & $\begin{array}{l}\text { Non compliance. } \\
\text { There have been identified cases where many } \\
\text { terms were used to refer to the same concept, } \\
\text { such as "messages" and "conversation" on } \\
\text { Messenger. } \\
\text { "Ads" with "publicity", "publications" with "news". }\end{array}$ \\
\hline
\end{tabular}


Priority: II

Sources: Nielsen; Hassan et al. There must be a visual consistency.

\section{Priority: I}

Sources: NIA; Finn et al. Use of homogeneous templates and standardized designs to similar tasks.

Priority: II

Sources: Finn et al.; Nielsen Coherence dependent components.

\section{Non compliance.}

There are pages on Facebook that do not have the visual coherence of the others (Figure 20). It is the case of Ad Preferences, Ads, Games, Setting options that appear in different places.

Non compliance.

Homogeneous designs are not found in similar places where there should have them, such us posting from the homepage or the wall. As well as the See More in Messages, which is different from the See More in Notifications. The Notification Setting opens a new window while the Friend Request Setting does not. Compliance. No problem was identified in this regard.

\section{The figures of this section are:}
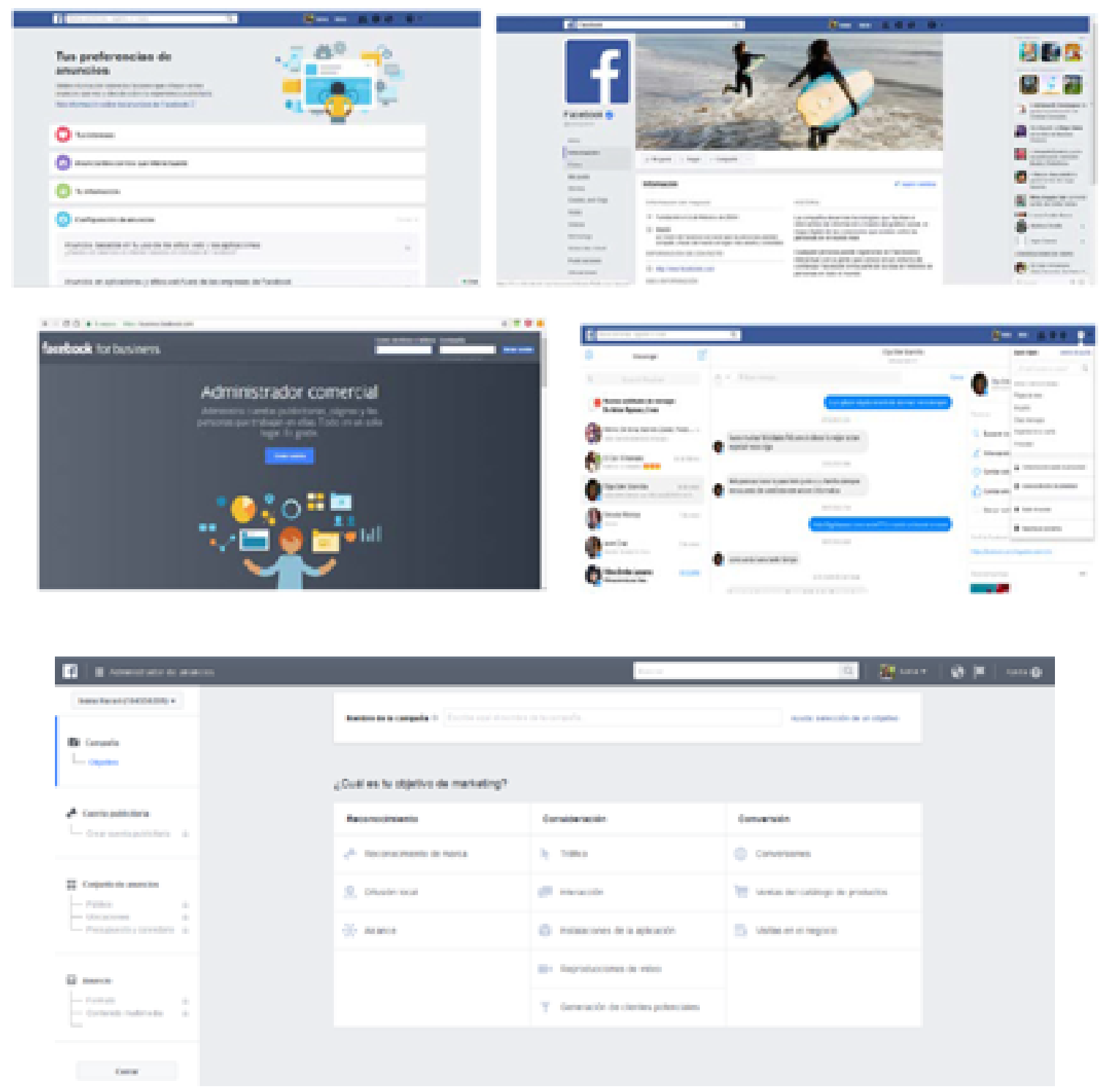

Figure 20: Non visual coherence. Several sections and pages of Facebook with different designs 


\subsection{Heuristic evaluation regarding useful and significative feedback}

Users should always be kept informed about the status of the system, transactions and validations as well as where the focus of the mouse or keyboard is located. The system must always keep older users informed about the effects of the actions performed by them or others.

There are 4 recommendations that aim to analyze this issue. The Table 8 will show the heuristic evaluation results regarding feedback.

Table 8: Heuristic evaluation according to visual and terminological consistency

\begin{tabular}{|c|c|}
\hline HEURISTIC & COMPLIANCE EVALUATION \\
\hline $\begin{array}{c}\text { Priocity. II } \\
\text { Sources- Nintsen; Hassan et al : NIA } \\
\text { Provide information notices, clarifying. } \\
\text { preventive, confirmation and closing } \\
\text { messsages. }\end{array}$ & $\begin{array}{l}\text { Non compliance. } \\
\text { Provide some clarifying messages. Sometimes } \\
\text { fendhack with tips and sometimes not Some } \\
\text { messages do not add any new intormasion, they } \\
\text { just repeat the title of the option. } \\
\text { There are cases in which feedback is not even } \\
\text { present. }\end{array}$ \\
\hline $\begin{array}{c}\text { Priority: I } \\
\text { Bource: Nielsen } \\
\text { Per form validations. }\end{array}$ & $\begin{array}{l}\text { Compliance. } \\
\text { It performs authentications. }\end{array}$ \\
\hline $\begin{array}{l}\text { Priority. I } \\
\text { Sources: Nielsen; Hassan et al. } \\
\text { Provide information about the status of } \\
\text { the processes, of the system, } \\
\text { transactions. }\end{array}$ & $\begin{array}{l}\text { Non compliance. } \\
\text { It provides feedback for delays but in different } \\
\text { formats and effects (Figure 21). }\end{array}$ \\
\hline $\begin{array}{l}\text { Priority II } \\
\text { Sourcee: Nieleen; NIA; Finn et al. } \\
\text { Good error meeeagee that are not } \\
\text { intimidating and give useful information } \\
\text { to get cut of that state. }\end{array}$ & $\begin{array}{l}\text { Complianec. } \\
\text { The error meseagee are adequate. }\end{array}$ \\
\hline
\end{tabular}

Source: Elaborated by the authors according the research done

The figures mentioned in this section are:

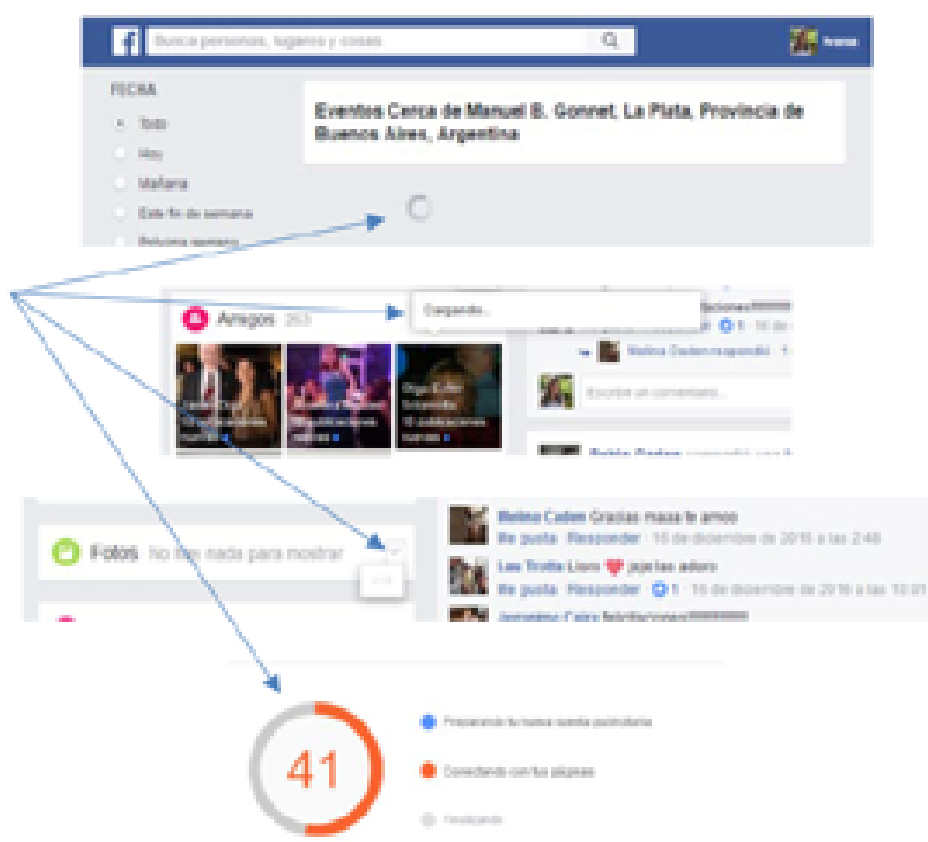

Figure 21: Some feedback inconsistency detected in Facebook 


\subsection{Heuristic evaluation regarding simple and efficient navigation}

The usability inspection applied to Facebook regarding navigation aspects will be explained in Table 9. Navigation must be clear, with a certain logic that prevents the older user from losing context and allows him or her to easily find what is required.

Table 9: Usability evaluation considering navigation principles

\begin{tabular}{|c|c|}
\hline HEURISTIC & COMPLIANCE EVALUATION \\
\hline $\begin{array}{c}\text { Priority: I } \\
\text { Source: Hassan et al. } \\
\text { Clear identification of internal and } \\
\text { external links, their states. Consistent } \\
\text { titte of the link with the titte of the linked } \\
\text { page. }\end{array}$ & $\begin{array}{l}\text { Non compliance. } \\
\text { Some links lead to pages without a respective title } \\
\text { or heading, such as clicking in Message Settings } \\
\text { lead you to Facebook Account. The create Ad } \\
\text { Settings option take you to an advertisement } \\
\text { administration page (Figure 22). }\end{array}$ \\
\hline $\begin{array}{c}\text { Priority: I } \\
\text { Sources: NIA; Finn et al. } \\
\text { Large and distinguishable icons, } \\
\text { buttons, links and clickable areas. }\end{array}$ & $\begin{array}{l}\text { Non compliance. } \\
\text { The clickable areas as well as the icons, arrows or } \\
\text { links are small, not the recommended size. }\end{array}$ \\
\hline $\begin{array}{c}\text { Priority: III } \\
\text { Sources: Hassan et al.; NIA } \\
\text { Avoid unsuccessful navigation steps, } \\
\text { broken links, outdated information. }\end{array}$ & $\begin{array}{l}\text { Compliance. } \\
\text { No problem was identified in this regard. }\end{array}$ \\
\hline $\begin{array}{l}\text { Priority: II } \\
\text { Sources: Nielsen; Hassan et al. } \\
\text { The information, functions or services } \\
\text { must be found quickly and easily, in a } \\
\text { few steps. }\end{array}$ & $\begin{array}{l}\text { Non compliance. } \\
\text { What is immediate is what is recent. What is old } \\
\text { takes time to locate. Pages with extensive content } \\
\text { do not have an index nor do they have a search } \\
\text { system. } \\
\text { The only way to have an organized display by year } \\
\text { is to go to the Activity Log. }\end{array}$ \\
\hline $\begin{array}{l}\text { Priority: I } \\
\text { Sources: Hassan et al.; W3C } \\
\text { Avoid opening tabs or windows that } \\
\text { disrupt browsing. }\end{array}$ & $\begin{array}{l}\text { Non compliance. } \\
\text { Many functions open in independent tabs, such as } \\
\text { publicity settings on Facebook. }\end{array}$ \\
\hline $\begin{array}{c}\text { Priority: I } \\
\text { Sources: NIA; W3C } \\
\text { Avoid automatic scrolling or provide big } \\
\text { icons in scroll bars. }\end{array}$ & $\begin{array}{l}\text { Compliance. } \\
\text { There are no big icons to manipulate the scroll but } \\
\text { it can be handled with the keyboard. }\end{array}$ \\
\hline $\begin{array}{l}\text { Priority: II } \\
\text { Sources: Nielsen; NIA } \\
\text { Provide navigation back and forth. } \\
\text { Avoid the use of browser functions. }\end{array}$ & $\begin{array}{l}\text { Non compliance. } \\
\text { There is no navigation back or forth. } \\
\text { There are situations where there is no way to go } \\
\text { back, for example when an error occurs the Quit } \\
\text { option closes Facebook (Figure 23). }\end{array}$ \\
\hline
\end{tabular}

Source: Elaborated by the authors according the research done

The figures showing some usability errors analyzed in this section, are:

Page option links to a page without title:

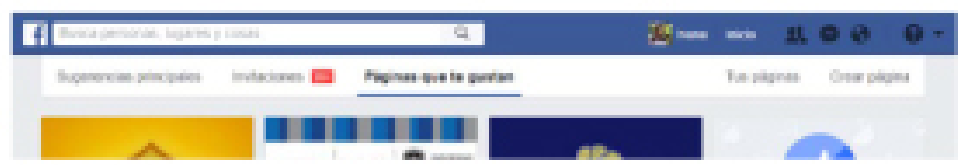


Adapting usability heuristics to evaluate

Facebook according to elderly

Create Ads links to a page titled Ads Setting:

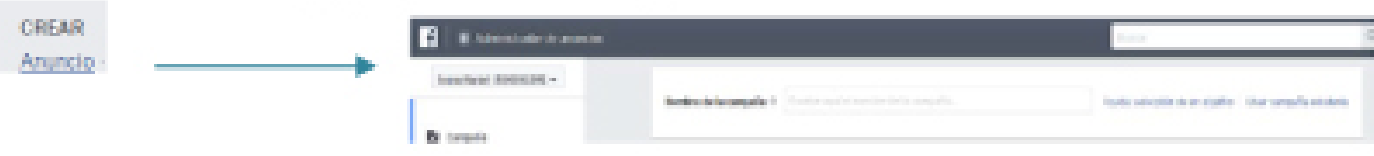

The See All option in Friends request section is linked to a untitled page:

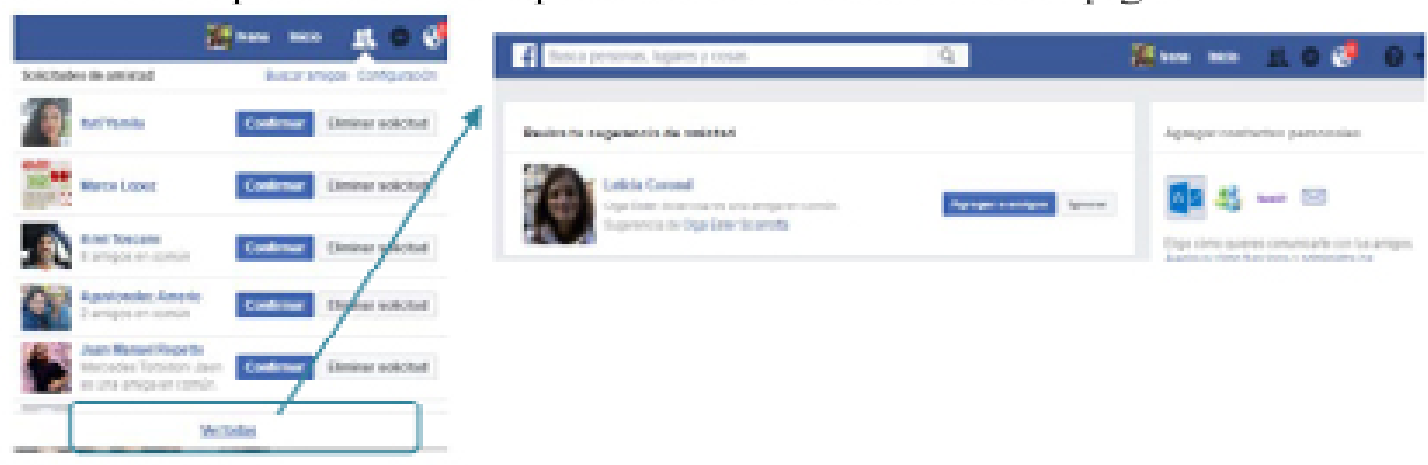

The Page Admin option links to a page titled Pages:

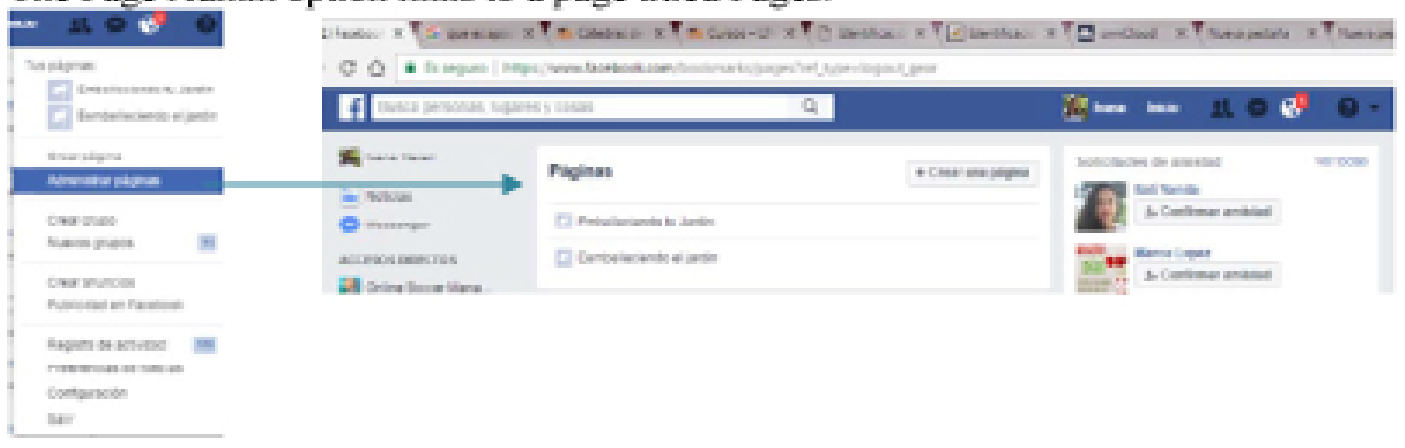

The Publicity on Facebook option links to Facebook for Enterprises:

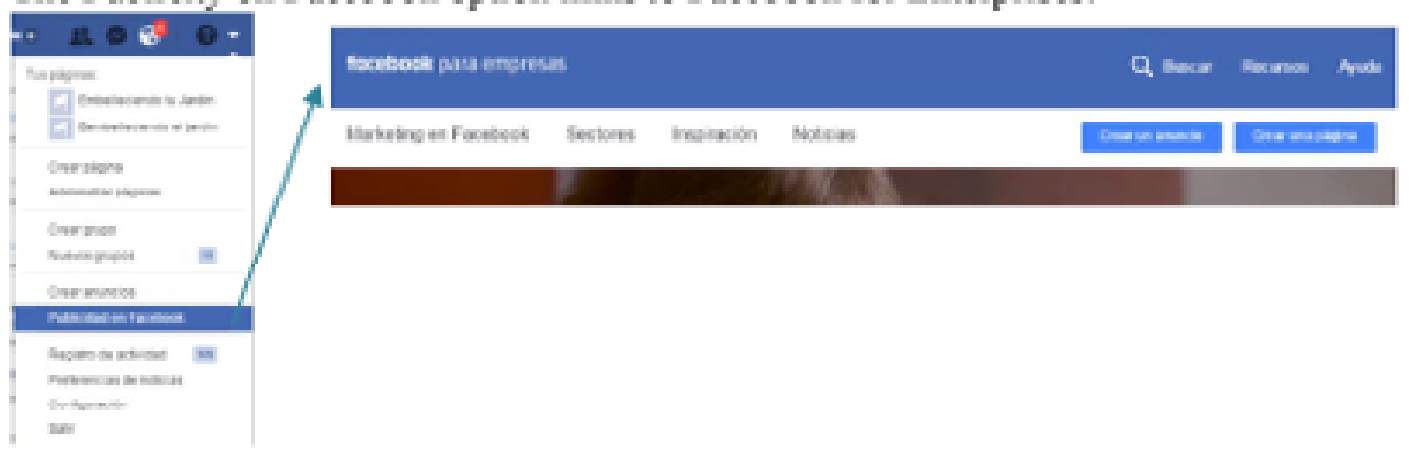

Figure 22: Inconsistent titles of the link with the titles of the linked page
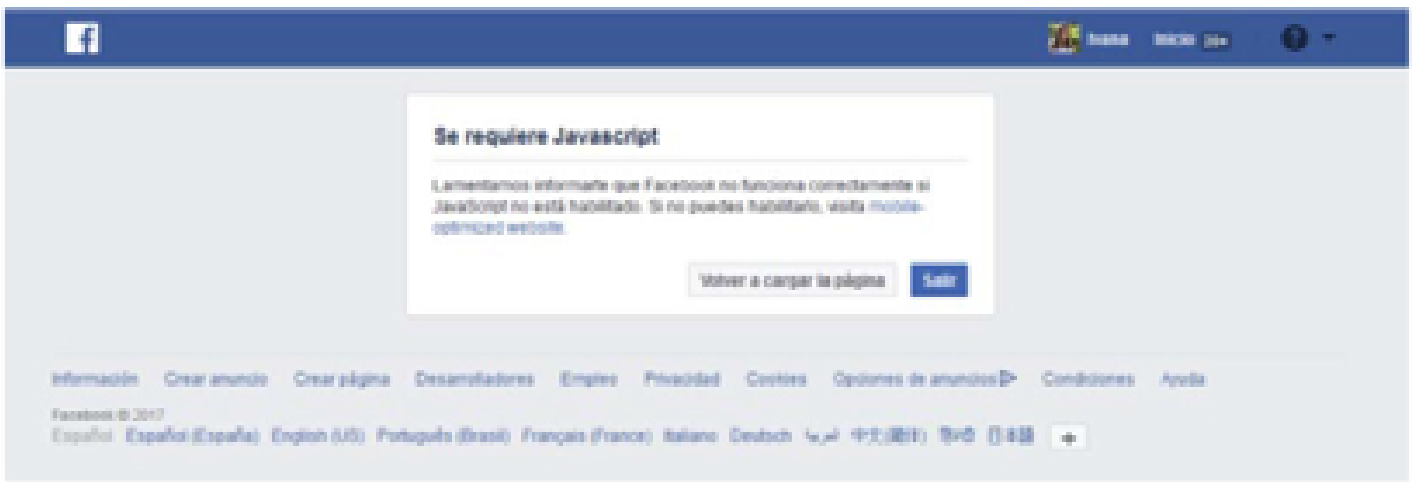

Figure 23: The Quit button of an error message closes all Facebook without warning 


\subsection{Heuristic evaluation regarding groupware features}

What concerns collaborative work and group interaction must be dealt with coherently and explicitly even more if elderly people are involved in it. It should guarantee the user that he or she is in an activity or that the content being dealt with is private and not a group activity.

The system cannot act as a black box, where the actions of the user as well as those of another member of the group, are processed without giving explicit indications of what is being done, of the effects both local and global, or of the status resulting from such action.

The evaluation of Facebook taking account usability heuristics about groupware aspects, yielded the results shown in Table 10.

Table 10: Heuristic evaluation according to groupware aspects

\begin{tabular}{|c|c|}
\hline HEURISTIC & COMPLIANCE EVALUATION \\
\hline $\begin{array}{c}\text { Prionity: I } \\
\text { Sources: Nielsen; Grudwin et al. } \\
\text { Distinguish local from global. Shared } \\
\text { objects from those which are not. } \\
\text { Collaborative functions from those } \\
\text { which are not. }\end{array}$ & $\begin{array}{l}\text { Non compliance. } \\
\text { There are functions and transactions that are } \\
\text { private but they are mixed with those that are not. } \\
\text { Public content is not distinguishable from that which } \\
\text { is local. There are no explicit indicators. (Figure 24). }\end{array}$ \\
\hline $\begin{array}{l}\text { Priority: II } \\
\text { Sources: Grudwin et al.; Hewitt et al. } \\
\text { Show the multiuser feedback. } \\
\text { Distinguish between the effects of the } \\
\text { actions performed by the user and } \\
\text { those performed by others. }\end{array}$ & $\begin{array}{l}\text { Compliance, } \\
\text { In notifications and activity log, it is expressed what } \\
\text { is performed by others that concerns or affects the } \\
\text { user. }\end{array}$ \\
\hline $\begin{array}{l}\text { Priority: ॥ } \\
\text { Sources: Nielsen; Hewitt et al. } \\
\text { Make the interaction of the users } \\
\text { explicit. }\end{array}$ & $\begin{array}{l}\text { Compliance. } \\
\text { Facebook, states what was the action that caused } \\
\text { such effect in the group context. }\end{array}$ \\
\hline $\begin{array}{c}\text { Priority: II } \\
\text { Source: Grudwin et al. } \\
\text { Provide awareness of who, where, and } \\
\text { what the members of the group are } \\
\text { doing. }\end{array}$ & $\begin{array}{l}\text { Non compliance. } \\
\text { There is an awareness of those that meet through } \\
\text { the chat, but not of the information they are } \\
\text { developing or in which sector they are at in a } \\
\text { certain moment. }\end{array}$ \\
\hline $\begin{array}{l}\text { Priority: I } \\
\text { Sources: Nielsen; Grudwin et al. } \\
\text { Provide clear information of what is } \\
\text { shared and to whom it is spread. }\end{array}$ & $\begin{array}{l}\text { Non compliance. } \\
\text { There are no clear and explicit indexes of what is } \\
\text { shared and what is not. It is not clear whether he } \\
\text { information that is detailed in the Biography or } \\
\text { information in your Profile is shared publicly or not. } \\
\text { It is not known whether blocking or changing the } \\
\text { friend status to Acquaintance is shared. } \\
\text { The functions of a post published by another user in } \\
\text { your profile, it is unknown whether that user will be } \\
\text { notified in the case you delete, save, print or hide } \\
\text { that post (Figure 25). }\end{array}$ \\
\hline $\begin{array}{l}\text { Priority: I } \\
\text { Sources: Nielsen; Grudwin et al. } \\
\text { Show information of the status of the } \\
\text { user, object or place shared. }\end{array}$ & $\begin{array}{l}\text { Non compliance. } \\
\text { There is no information of who is looking at your } \\
\text { photos at a given moment, nor of the status of the } \\
\text { members except for whether they are online or not }\end{array}$ \\
\hline
\end{tabular}


Adapting usability heuristics to evaluate Facebook according to elderly

\begin{tabular}{|c|c|}
\hline $\begin{array}{c}\text { Priority: I } \\
\text { Sources: NIA; W3C; Hewitt et al. } \\
\text { Make the group access strategy } \\
\text { explicit, by turn, token, floor control. }\end{array}$ & $\begin{array}{c}\text { Compliance. } \\
\text { Access set by the same user. }\end{array}$ \\
\hline $\begin{array}{l}\text { Priority: I } \\
\text { Sources: Hewitt et al.; Nielsen } \\
\text { Make the functionality and feedback } \\
\text { explicit provided they are at the group } \\
\text { or individual level. }\end{array}$ & $\begin{array}{l}\text { Compliance. } \\
\text { There are explicit signs of the group interaction. }\end{array}$ \\
\hline $\begin{array}{c}\text { Priority: III } \\
\text { Sources: Nielsen; NIA; Hewitt et al. } \\
\text { Degree of support at the individual and } \\
\text { group levels. }\end{array}$ & $\begin{array}{l}\text { Non compliance. } \\
\text { There are none at the group level. }\end{array}$ \\
\hline $\begin{array}{l}\text { Priority: III } \\
\text { Sources: Nielsen; Grudwin et al. } \\
\text { Provide ways to control the spread or } \\
\text { aspects of groupware. }\end{array}$ & $\begin{array}{l}\text { Compliance. } \\
\text { In most of the groupware actions, the privacy } \\
\text { settings can be configured in Setting options but for } \\
\text { example, the biography and other content cannot. }\end{array}$ \\
\hline
\end{tabular}

Source: Elaborated by the authors according the research done

The figures mentioned in this section are:

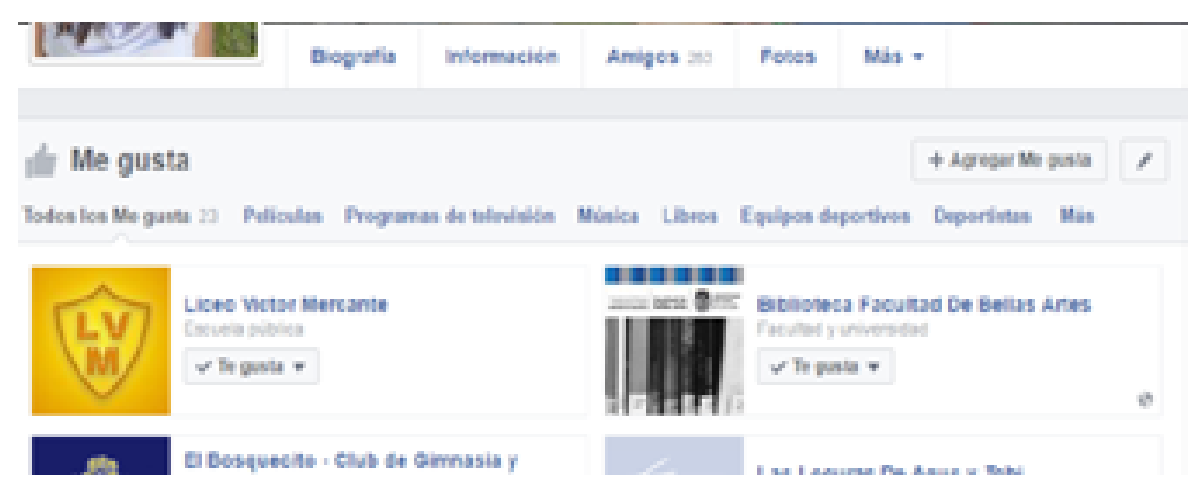

Figure 24: In the Like Panel the user doubts about which are the functions with global scope and which not

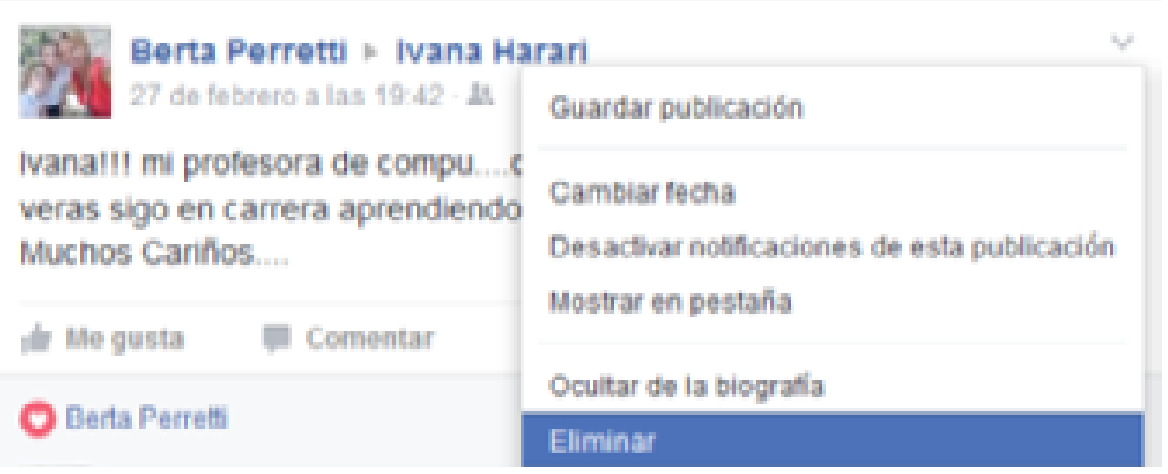

Figure 25: Without explicit indicators about the effect of actions over posts published by other in your Profile page. It is not clear for elderly which of the functions is a propagatable function and which is not

\section{Results of the heurist evaluation process}

The usability heuristic guide applied in the study, which was adapted for older adults and for their interaction with social networks, was very important. Allowed us to analyze the usability of a software product taking into account specific issues such 
as the user profile and the type of application with collaborative characteristics.

Usability is a concept dependent on context and so are the usability methods that are applied to measure and examine it.

The final results of the heuristic evaluation carried out on Facebook, where 65 adaptive and specific heuristic guidelines were applied, are:

- 10 from 32 guidelines with priority 1 complied

- 8 from 25 guidelines with priority 2 complied

- 1 from 8 guidelines with priority 3 complied

The web application could have and ideal rating of 154 points if all of them are complied, since there are 32 heuristics of priority 1 that are assigned three points if they are complied, 25 heuristics of priority 2 that are assigned two points, and 8 heuristics of priority 3 that are assigned one point as is explained in Table 1.

In this case, Facebook has 47 points from that 154 total points, a 30,51\% of usability considering the adaptive heuristics developed.

Although it has been evaluated with a particular set of usability rules, the results show usability problems that would lead to future problems of interaction, use and learning by older users.

\section{Conclusions}

A new challenge arises nowadays for web developers where older people have to be incorporated as potential users of web applications that are complex in their dynamism, multiuser participation, collaboration services and sharing. This becomes even more difficult when older users access these resources and makes us question how current applications are being developed and if they are designed considering this community of users.

For this purpose, this study describes a process of usability inspection of one of the most popular social networks, that is, Facebook. The ever-increasing approach by an age group in society that is made up by people of a third or fourth age, to the use of this social network is the reason behind this study.

This is motivated by the need for researches that account for and evaluate whether these applications are being designed to provide a quality of interaction to a user with these characteristics. In order to achieve this, heuristics from important authors in $\mathrm{HCl}$ literature were gathered, integrated and adapted according to the profile of the older adult and the type of application, which is a collaborative application or groupware.

According to a specific set of heuristics, this evaluation led to unsatisfactory results with regards to usability, taking into account that is an important and popular application that influences and modifies the future user interfaces design. It has been proved that despite their popularity, they present important usability problems; they do not comply with recommendations that must be observed and considered in future versions of web development because they not only affect young users but also 
the next digital consumers: the older adults.

\section{REFERÊNCIAS}

FINN, Kate and JONHSON, Jeff. Designing for Older Adults: Usability Considerations for Real Users. www.wiserusability.com/author/adminjeff/, 2014.

GUTWIN, Carl and GREENBERG, Saul. Implications of We-Awareness to the Design of Distributed Groupware Tool". Journal, Computer Supported Cooperative Work, 25:279-293. Springer, October, 2016.

HASSAN MONTERO, Yusef and FERNANDEZ MARTIN, Francisco. Guía de Evaluación Heurística de Sitios We". NSU- No Solo Usabilidad. Nro.2, 2003.

HEWITT B. y GILBERT G.N. Groupware Interfaces. En CSCW in Practice: an Introduction and Case Studies. Editorial Springer Science \& Business Media, 1993.

HUTCHINS, Edwin; HOLLAN, James y NORMAN, Donald. Direct Manipulation Interfaces. Human Computer Interaction. Vol.1. Lawrence Erlbaum Associates, Inc. University of California, San Diego, 1985.

NIA- National Institute on Aging. Making your website senior friendly. National Library of Medicine, USA, 2002.

NIELSEN, Jakob. Usability engineering. Academic Press Inc., Boston, 1993.

NORMAN, Donald y DRAPER, Stephen. User Centered System Design: New Perspectives on Human-computer Interaction. Lawrence Erlbaum Associates Publishers, Londres, 1986.

OLDMEADOW, Julian; QUINN, Sally and KOWERT, Rachel. Attachment style, social skills, and Facebook use amongst adults. Journal of Computers in Human Behavior 29. Elsevier, 2013.

W3 Consortium. Web Accessibility and Older People: Meeting the Needs of Ageing Web Users. Education and Outreach Working Group (EOWG), related to the WAI-AGE, 2010.

WHO- World Health Organization. World Health Stadistics Report. Ginebra: WHO Press, 2014. 